\title{
Believer Perspectives on Death and Funeral Practices in a Non-believing Country*
}

\author{
OLGA NEŠPOROVÁ** \\ Research Institute for Labour and Social Affairs, Prague
}

\begin{abstract}
The article describes attitudes towards death and funeral rites in contemporary Czech society. It begins by revealing the attitudes to death held by the majority of the Czech population - non-believers. The customary secular funeral ceremony, held in a crematorium, is not entirely well suited to meeting the needs of the bereaved, and this is borne out by the fact that about one-third of all cremations are held without a funeral ceremony. The author argues that the current situation is not solely the result of the economic situation of individuals but also stems from the deeply rooted attitudes and values and the approach to religion of the Czech population. The second part of the article is devoted to the attitudes towards death and the funeral rite preferences of believers, based on a survey conducted with members of three religious groups: Roman Catholics, Protestants (Church of the Czech Brethren), and Jehovah's Witnesses. Finally, the author compares the attitudes of the secular majority and believers, and also outlines the connections between conditions today and under the former communist regime regarding the general approach to death and funeral rites.
\end{abstract}

Keywords: Czech Republic, death, last rites, funeral, believers

Sociologický časopis/Czech Sociological Review, 2007, Vol. 43, No. 6: 1175-1193

\section{Introduction}

Funeral practices are always closely related to attitudes towards death and conceptions of the afterlife. Among the majority of the population in the Czech Republic, a country with a forty-year communist legacy, there are still deeply rooted taboos concerning death and issues relating to death. Many people try to avoid talking about death and dying, and consequently many people who have to cope with the death of a relative or a friend minimise the funeral ritual. In the com-

\footnotetext{
* This study was supported by grant no. 403/06/0574 from the Grant Agency of the Czech Republic for the project 'Detraditionalisation and Individualisation of Religion in the Czech Republic and Their Socio-political and Socio-economic Consequences'.

** Direct all correspondence to: Olga Nešporová, Research Institute for Labour and Social Affairs, Palackého náměstí 4, 12801 Prague 2, Czech Republic, e-mail: Olga.Nesporova@ vupsv.cz.
}

(C) Sociologický ústav AV ČR, v.v.i., Praha 2007 
munist era, the subject of death was regarded as taboo in the public domain, an approach similar to that of Western society on the whole for the better part of the 20th century. However, unlike in the West, where improper conditions for terminal patients in hospitals ${ }^{1}$ led in the 1960 s to a more open discussion on the subject of death and dying both in the academic and non-academic spheres, death remained taboo in Czech society right up to the end of the 20th century. Fortunately, the situation is now changing, people are very slowly becoming more open about how they deal with death and dying, and death is once again becoming an accepted part of life [Kalvach et al. 2004]. The modern hospice movement, led by Cicely Saunders in the 1960s in England, only began establishing itself in the Czech Republic in the mid-1990s. ${ }^{2}$ There are currently (in 2007) fourteen hospices (two of them home hospices) in the country.

The majority of the Czech population claims to be atheist or to have no religious belief. The term 'atheist' has a special and broader meaning in the Czech context. It is often regarded as a term that expresses general opposition to members of an organised church, rather than a person who does not believe in the existence of God. The reasons for this lie primarily in the legacy of the various, often turbulent, historical events that led to the formation of the present-day Czech Republic (including secularisation and the communist regime) and to a strong aversion on the part of a large number of Czechs to organised religion [Nešpor 2004]. According to the 2001 census, only about $32 \%$ of Czechs claimed to belong to a church ( $84 \%$ of whom were Catholics), 59\% declared themselves non-believers/atheists, and $9 \%$ did not answer the question on religious beliefs. Interestingly, many of those claiming to be non-believers / atheists do in fact hold some kind of personal beliefs, most often comprising a mixture of the occult, magical healing practices, eastern religious ideas, talismans, and various divination practices such as horoscopes, palm reading, etc. In a study based on data contained in the 1998 International Social Survey Programme, D. Hamplová concluded that Czech religiousness can be divided into two different groups: 'On the one hand, it is a belief in God embedded in the Christian doctrine; on the other it is an occult-based religious fatalism coupled with a spiritual orientation which might well be termed a belief in man.' [Hamplová 2000: 57-58]

\footnotetext{
${ }^{1}$ The hospital conditions for dying patients were no better in the Czech Republic, but it was unacceptable to focus too much attention on this issue since a good universal health service was seen as one of the great achievements of socialism; pointing out any inadequacies was felt to be politically and personally unwise.

${ }^{2}$ Marie Svatošová is credited with introducing the modern hospice movement to the Czech Republic.
} 


\section{Dealing with death in a secular majority}

The existence of the communist regime in the former Czechoslovakia, with its overriding antireligious stance, was undoubtedly one of the reasons that the subject of death came to be so deeply hidden [see Nešporová 2007]. It was not advisable to talk about death, for which communist ideology offered no satisfactory explanation. Communist dogma, striving ceaselessly to eradicate religious ideas in any form, had little to offer the people for overcoming death, reducing their fear of death, or coping with bereavement. As Berger and Luckmann [1967] have pointed out, one of the most important tasks in any society is legitimating death. According to those authors, death obtains legitimacy through the existence of symbolic universes, which serve to explain and justify social reality. There is a strong need in every society to cope with death and to legitimise its place in society, since the awareness of death, a knowledge specific to humankind, and the fact of death, can underpin the meaning of society as a whole [Malinowski 1948]. Therefore, in most societies, death is a highly ritualised event, accompanied by certain rites that take place while a person is dying, and often more elaborate ones taking place after death. Last rites rank among the so-called rites of passage (together with birth, initiation and marriage [Gennep 1960]), which give structure to human life, and during which the new social stage that the key actors are in acquires social acceptance, secured from the collective character of the rites or their parts.

Communist doctrine was singularly unsuccessful in its attempts at legitimating death, claiming that it meant the end of human existence, and condemning the ideas of an afterlife and resurrection as fables. The system attempted to comfort people (the dying as well as the bereaved) by referring to lifetime achievements, particularly in terms of work. It was even felt that reconciliation with death would be achieved from an awareness that the results of a person's lifetime work would live on [Steindl 1987]; there was no promise of an afterlife as there is in most religious concepts. Perhaps not surprisingly, given that most people found the idea of reconciliation with death through work unappealing, ${ }^{3}$ they tended to avoid thinking and talking about death completely. It has been suggested that such an attitude could have been reinforced by personal experiences of the Second World War [Jupp and Water 1999], and to some extent also by an attempt, in the public domain, not to draw attention to information concerning the mass murders committed by the communist regime in Russia. In short, death and dying was taboo. Notions of an afterlife were derided as the inventions of false religious doctrines.

However, the need for the ritualisation of liminal stages of life [Gennep 1960; Turner 1974] was reflected, and the communist regime introduced the concept of

\footnotetext{
${ }^{3}$ This was particularly relevant in a society where many people were not free to choose their work and for whom promoting the socialist ideal was in conflict with their personal convictions.
} 
the secular funeral ceremony, based on the Russian antireligious model [see Merridale 2000: 336-7, 354-6], to replace the traditional religious ceremony. Although the secular funeral had never been particularly popular in Russia, where the Russian Orthodox Church was opposed to the practice of cremation and where more than $60 \%$ of the population demanded some kind of religious ritual [Merridale 2000: 336], it was widely accepted in Czech society during the forty years of communist rule. Archive data about the numbers of funerals conducted by the Roman Catholic Church in the mid-1950s and from 1967 to 1988 clearly show that citizens of the Czech Socialist Republic were gradually abandoning Catholic funeral ceremonies $^{4}$. While Catholic funerals were held for about 75\% of all deceased in 1955, over the next thirty-two years the figure decreased by nearly half, and Roman Catholic funerals were held only for 39\% of the deceased in 1988 [Babička 2005: 478-480]. Consequently, most funeral ceremonies have been civil since $1980^{5}$ and only in exceptional cases could the funeral be entirely omitted under the communist regime. In rural areas, especially in Moravia, the replacement of the religious funeral ceremony with a state civil ceremony was less successful than in towns [Navrátilová 1989: 154]. The situation in the Slovak Socialist Republic, the other half of the federation at that time, was very different owing to the much more widespread and stronger affiliation of Slovaks to Christian churches (mainly the Roman Catholic Church); therefore, funerals retained their Christian forms [Kandert 2005].

The civil ceremony was a drab event held in the hall of a crematorium or in a civic funeral hall, and included an impersonal speech briefly describing the deceased's life, their work and social contributions, and, when relevant, possibly also their Communist Party activities. The speech was accompanied by either live or recorded music. The widespread acceptance of this kind of funeral ceremony could be explained by the already existing atheistic social climate and the fact that Czechs were quite open to the idea of cremation. Unlike Orthodox Russians, many Czechs favoured cremation even before the communists came to power. The Czech Cremation Association was founded in 1909 and the first cremation took place in Liberec ten years later. Although Catholics did not recognise cremation as an alternative to burial until the 1960s, Protestant churches had no objection to this method of disposal. The Czechoslovak Church (since 1971, the Czechoslovak Hussite Church) even started to build columbaria in their chapels or cemeteries to hold the cremated remains. Nevertheless, the majority of people who favoured cremation were atheists.

\footnotetext{
${ }^{4}$ Catholic ceremonies were the norm until the middle of the 20th century. Funerals were quite elaborate, with wakes and funeral processions, in which many people took part, and mourning was also customised according to the relationship of the bereaved to the deceased; see Navrátilová [2004].

${ }^{5}$ No data are available on religious funeral ceremonies conducted by other churches, but it is clear from the small proportion of believers other than Roman Catholics in Czech society that the figures must be very low and represent only an insignificant proportion of all funeral ceremonies.
} 
Today, the death rituals practised by the majority of Czechs could be seen as a reaction to the model introduced by the communist regime. It is not the cremation itself that is seen as inappropriate, but the civil ceremony held in the crematorium hall and especially the standard speech on the various contributions of the deceased. There is often an absence of any deeper meaning to it. According to information provided by the Czech Cremation Association, $78 \%$ of people who died in the Czech Republic in 2005 were cremated. ${ }^{6}$ Standard secular funerals today are held in an atmosphere similar to that in the 1970s and 1980s. The speech is formal and usually given by a professional speaker provided by the crematorium, who has no personal relationship with either the deceased or the bereaved, to whom the speaker is introduced no more than a quarter of an hour before the funeral ceremony commences. The speaker talks about the deceased based on information provided by the bereaved, which is fitted into a 'template' or universal speech that usually lasts only about five minutes. The brevity of the funeral address is perhaps not surprising since a speech celebrating the working life and social contributions of the deceased may seem insincere when read by someone who had never met them, and since there is little point in talking of the future when there is no conception of an afterlife.

The author is convinced that this kind of ceremony does not correspond to the needs of the bereaved, and sees the inadequate ceremony, coupled with an aversion to organised religion and therefore also to its traditional rituals, as the main explanation for the significant decrease in the number of funeral ceremonies held. The contemporary secular funeral ceremony is not meaningful for some people [cf. Walter 1994], which is the reason why some relatives decide against holding a funeral ceremony. Funeral directors do not work with the emotions of the bereaved, and they do not provide their clients with much emotional support (the opposite is true in New Zealand, where secular funerals are also quite common; cf. Schäfer [2007]). There is no satisfactory solution for helping bereaved people to cope with the loss of a loved one or someone close to them; the old social and religious ways do not work any more and new ones have not yet established themselves. Bereavement organisations do not exist (with the exception of a few new organisations, often hospices, with very limited target groups). In difficult cases the bereaved can seek the help of a psychologist or psychiatrist, but this is not common [Kubíčková 2001].

Czechs themselves most often cite how expensive the ceremony is as an explanation for omitting it [Haškovcová 2000: 94], but that alone is an insufficient reason, as the prices (in proportion to wages) ${ }^{7}$ are not significantly higher com-

\footnotetext{
${ }^{6}$ According to data from the Cremation Society of Great Britain, available at: http://www.srgw.demon.co.uk/CremSoc5/Stats/Interntl/2005/StatsIF.html. (Retrieved September 2007).

7 The cost of a funeral with a ceremony (either cremation or burial) can range between 440 Euro (12 000 Czk) and 910 Euro (25 000 Czk), but it can cost much more when special quality and extra services are included. Cremation without a ceremony costs around 290
} 
pared to other countries; rather the opposite is true. They also frequently argue that it is the emotional stress they are trying to avoid by omitting the funeral ceremony. They do not want to reawaken thoughts of the deceased, which inevitably happens during a funeral ceremony. This is not a very strong argument on its own, because it is hard to believe that they could forget the deceased just by avoiding a funeral ceremony, and in fact that is not what they want. But Czech society (like in Britain; see Walter [1999]) favours more reserved expressions of grief, and this choice enables them to avoid an emotionally stressful situation in the presence of others. It is a short step from holding a private ceremony for just a narrow circle of relatives (which Czechs often do nowadays) and omitting it altogether. When a ceremony is not seen as being somehow useful for the future existence of the deceased, for honouring the dead, or useful for the bereaved, then some bereaved decide to omit the funeral ceremony. Another reason that may warrant mention here is the anonymous nature of city life and the decline in mutual dependency which characterises traditional communities.

In approximately one-third of all Czech cremations no ceremony is organised through an undertaker, which, in most cases, means that no funeral ceremony is held..$^{8}$ A typical ceremony in a crematorium consists of listening to recorded music recommended by the management of the crematorium. The songs are chosen by the bereaved from a list provided by the funeral director, usually with some connection to the deceased. The bereaved can also bring their own CDs to be played during the ceremony if the music offered does not suit their taste. In the small crematorium hall at the Prague-Strašnice crematorium, the standard ceremony lasts a maximum of twenty-five minutes, only five minutes of which are usually devoted to the speech ${ }^{9} ; 28 \%$ of the funerals held there in 2004 consisted only of music without a speech [Maiello 2005]. In most cases the ashes are buried in a grave or deposited in a columbarium. Only a small number of cremations are followed by the scattering of the ashes.

\section{Research amongst Czech believers}

Qualitative research aimed at observing the attitudes of believers towards death and other related topics was conducted in Prague in 2003 and 2004. Three different religious groups belonging to three different churches were contacted in

\footnotetext{
Euro (8000 Czk). In 2006 average monthly earnings were 740 Euro (20 211 Czk). Moreover, a universal social benefit at a fixed amount of 180 Euro (5000 Czk) is provided by the state to the person who arranges the funeral (this is valid till the end of 2007).

8 There are exceptions, especially amongst religious believers who prefer to organise the ceremony independently of an undertaker, sometimes without the presence of the body; for example, in the form of the Eucharist in the Catholic Church or a commemorative celebration in the Kingdom Hall of the Jehovah's Witnesses (see below).

${ }_{9}$ When a longer speech is planned, the family is asked to reserve double time.
} 
the field research. ${ }^{10}$ The sample contained one parish from each of the two main churches in the Czech Republic, the Roman Catholic Church and the Protestant Church of the Czech Brethren, and one smaller religious society that boasts a growing number of members and is currently the fourth largest religious group in the country, the Religious Society of Jehovah's Witnesses. The field research consisted mainly of semi-structured non-standardised interviews with believers, supplemented by participant and non-participant observation of each of the three religious groups, usually during religious services. In-depth interviews were conducted with the aim of discovering the attitudes of respondents in three main areas: first, ideas about death, dying, and the afterlife; second, attitudes towards suicide; and third, thoughts about funeral rites, their significance, and personal preferences. Below the author will focus on two of the above topics, namely, ideas about death and the afterlife, and funeral rites.

The interviewer asked as many general and open questions as possible, thereby leaving it to respondents to decide (either consciously or unconsciously) whether or not belonging to a specific religious group affected their opinions. Since the questions were related to death, which constitutes an important element in the doctrines of all the religious groups surveyed, membership of a religious group turned out to be of considerable importance in the respondents' answers. Respondents in each group usually shared similar ideas, especially in connection with the afterlife and the type of funeral preferred.

The research sample was created using purpose sampling, the basic criteria for the inclusion of an informant in the sample being active membership in one of the three selected religious groups, gender, and being between the ages of thirty and fifty. The mean age of the respondents was thirty-seven. The inclusion of any other criteria was accidental and depended primarily on the willingness of individual informants to give an interview on the subject of death. Informants were first contacted at their places of worship, usually after a service, and asked to take part in the research. The actual interview was then conducted at a time and place chosen by the respondent, most often at the place of worship or in a restaurant. Seven interviews were conducted for each of the three religious groups, one of which was with the leader of the respective congregation, i.e. a priest or elder, and three with male and three with female members of the group. A total of twenty-one interviews were conducted, recorded, transcribed, and analysed.

\section{Roman Catholics}

The research revealed that members of the Roman Catholic Church view death as a transition; as the end to earthly existence and at the same time as an inevitable

${ }^{10}$ In fact, a small non-Christian religious group was also researched, mostly for methodological reasons, but I do not refer to it in this paper. For more information see Nešporová [2004]. 
part of life. For Roman Catholics death is not the end but rather a turning point, after which, they are convinced, there is an afterlife. It was also found that most of those questioned believed that life is somehow pre-ordained and every human being has a pre-determined life span. Two respondents compared this process to a burning candle. In the words of Mr. L.:

I believe that when you are born, a candle is lit. You receive a piece of paper containing a description of your main features, character, and the things you can influence; a certain degree of flexibility is possible, but your life is pre-ordained. The candle burns to its end; some will enjoy long lives, some short.

The above quote reveals an obvious belief in destiny and a pre-ordained life span and in the unchangeable nature of man. However, this belief in individual destiny is not strictly fatalistic in all areas of human existence. One informant suggested that there are domains that are not pre-determined as such, and where a person is the architect of his or her own fortune. However, a person's life span itself is not one of these areas, and the fact that man has no idea of the duration of his life is viewed as important.

Catholic views of the afterlife were found to be very positive; respondents most often referred to notions of the afterlife as a blessed existence and, moreover, one substantially better than a person's earthly tenure. For instance, Mr. L. continued: '... then [after death] I will be fine. Nothing will hurt or worry me any more, therefore I will be fine'. Similar ideas were expressed by Mrs. M.:

... The Lord Jesus will take us to His heavenly kingdom, where there will be neither space nor time. There will be infinite happiness, infinite love, there will be no suffering, and this will mark the end to our earthly life. Thus flesh and bones will go to the grave or will be burnt and the soul will pass to another place.

The soul alone survives. The Catholics interviewed believed that the afterlife is positive and pleasant, without suffering or pain, in fact a paradise, according to two of the respondents. Other distinctive traits of the Catholic afterlife were its infinity and the presence of God.

The majority of the Catholic respondents shared a preference for traditional burial in a grave, and their reasons for this were closely related to following either church or family tradition. At the same time, singing and music were very often mentioned as important parts of the funeral rite. Mr. M. expressed the wish to have a big funeral:

The most important thing for me [at my funeral] is the music, music. It is essential that as many people as possible attend, friends and relatives, because I know that it will be important for them. 
This wish was expressed on several occasions and was closely linked to the conviction that the funeral rite helps the bereaved to mourn and to overcome the death of a loved one. However, not all Catholic respondents favoured a grand funeral ceremony attended by a large number of mourners. Mrs. M., for example, had an entirely different wish:

I would like to have a simple funeral, just the coffin and a Catholic priest, possibly with my husband and those to whom I was closest in life. No theatrics, but, above all, prayer. In my case it shall be in accordance with Christian law and in accordance with God's commandments.

In this case the respondent expressed a preference for simplicity, with few or no mourners present at the funeral, objecting to what she saw as the 'pomp' of the funeral ceremony.

Catholics were generally convinced that it is possible to influence the afterlife of the deceased, but their specific ideas about the relationship between the living and the dead varied. About half of the respondents believed in a two-sided relationship, with the living helping to improve the afterlife existence of the deceased through their prayers and thoughts, or by saying a requiem mass, and the deceased assisting the living as a kind of 'guardian angel'. Others believed in a relationship in which only one side, either the dead or the living, is able to affect the other. At the same time, Catholic respondents believed that neither the form of the funeral ceremony nor the method of dealing with the body could influence the afterlife of the deceased; only prayers and thoughts were considered as possibly having such an effect.

\section{Protestants of the Church of the Czech Brethren}

Protestant ideas of death and the afterlife were in many respects similar to those of the Catholics, but it was clear that certain concepts, especially concerning the afterlife, were less clear-cut. Members of the Protestant Church of the Czech Brethren perceived death as the beginning of a journey, a dividing line or a turning point in life, and at the same time they believed that physical death does not mean an end to life, since the soul is immortal. Unlike Catholics, the Protestants questioned (with the exception of one respondent) did not believe that the human life span is pre-determined. A number of respondents suggested that sudden or unexpected death is caused by the random coincidence of events; others suggested that such deaths simply cannot be explained.

Most of the Protestants questioned had no precise idea of the afterlife. A number of them claimed that their lack of any such vision was intentional; they are unwilling to formulate ideas about the afterlife because they are convinced their ideas will be wrong. Such an attitude is by no means intended to deny the 
reality of an afterlife. Instead, these respondents were reluctant to attempt to imagine things that are beyond normal human experience. They were comforted by the notion that their lives would continue after death, presumably in a form other than that assumed on earth. One respondent, Mr. B., expressed his ideas of the afterlife as follows:

Everyone has a different notion [of the afterlife] and they've probably got it wrong. When a person dies, having declared their belief in Jesus Christ, they then have the chance of eternal life. A person leaves this life and probably goes to God. Perhaps they assume a spiritual form; at any rate they are not material. I suppose the afterlife is, to a certain extent, concealed or hidden [to man]. Clearly a person should not concern themselves too much about these things and should be concerned about living their life somehow in the right way; people should leave this [eternal life] to God.

God's presence and the continued existence of the deceased in an immaterial form were the only two characteristics of the afterlife that Mr. B regarded as likely, and he declined to speculate further on the issue. A certain degree of resignation and trust in God was obvious from his comments, as was the implicit conviction that if he behaves well during his earthly existence, he may be sure that God will take care of his afterlife and that of his fellow believers.

Protestant respondents did not for the most part express a preference concerning the disposal of the body. Two respondents suggested that cremation might be a better choice, but neither insisted on this method of disposal. A number of the respondents went on to outline their specific ideas about the form a funeral should take, but most had no clear opinions on this topic. It is important to note that none of the respondents were actually opposed to the funeral ceremony. A Protestant pastor interviewed suggested that, according to the doctrine of his church, biding farewell to the deceased, delivering them up to God and giving thanks for their life were essential components of the funeral service. During the funeral speech he would:

...prefer not to talk too much about the deceased.... Mention of the deceased should certainly not exceed in length the most important part of the speech, that is, the part concerning God and his promises, and faith in Jesus Christ.

In the pastor's opinion the key part of the funeral ceremony should consist of remembering Evangelical teachings, and the personality of the deceased should in no way be allowed to overshadow this message. Two male respondents suggested that the most important part of the ceremony is when the priest reminds the congregation of the existence of an afterlife. Two female respondents mentioned the singing of hymns, and both of them expressed the wish to have their favourite hymns sung at their own funeral services. Two of those questioned intended to leave the decision about the precise form of the funeral ceremony to the bereaved, since they felt it was very important that their loved ones be pleased 
with the funeral. One went on to say that he would prefer no sad or heartbreaking speeches during his funeral. One male respondent even went as far as to express his wish to have a happy funeral with an atmosphere like that of a wedding or a 'send off' party for someone going to live abroad for a year or two.

According to Protestant respondents it is not possible to influence the afterlife of the deceased in any way. The main reason for the funeral ceremony is to help the bereaved cope with the death of a loved one. This reason resembles that of the special commemorative funeral ceremony of the Jehovah's Witnesses.

\section{Jehovah's Witnesses}

The research revealed that Jehovah's Witnesses hold complex but remarkably uniform attitudes towards death. Three respondents stated that they saw death as a punishment for the sins of Adam and Eve and in fact, according to their convictions, as something unnatural, since God's original intention was to bless man with eternal life. In addition, Jehovah's Witnesses understood death in opposition to life, i.e. as non-existence. Accordingly, no part of man exists after death; the dead cease to exist. Such confidence in non-existence seems to correspond with the alternative perception of the soul shared by Jehovah's Witnesses compared to both Catholic and Protestant respondents, who see the soul as the part of man that continues to exist after death. The Jehovah's Witness concept of the soul rejects Greek tradition. By the soul they mean the whole being, human or animal, which with death ceases to exist. However, it is important to note that non-existence is seen as a temporary state.

The Jehovah's Witnesses interviewed did not believe in a pre-ordained destiny governing the time and cause of death. All the respondents believed that sudden death was caused by chance and the effect of unpredictable events. However, those questioned (with one exception) felt that one could to some extent affect events through individual behaviour and the way of life. It was felt a person could prolong their life by avoiding smoking and the use of addictive drugs, by not telling lies, refraining from adultery, and living in harmony with Biblical law. It was agreed, however, that such observances are only factors that contribute to longevity, and that there is no guarantee that accidental and unpredictable events cannot strike at any time and without warning.

As mentioned above, in the view of Jehovah's Witnesses the afterlife does not commence immediately after death but after varying periods of non-existence. During that period the deceased's form and identity are somehow 'filed' in God's memory so that a person may eventually be returned to life on earth. However, resurrection will only come after Armageddon:

...thus, after God's intervention, when He removes all evil and the people who destroy the earth and commit evil, those who are not prepared to acknowledge God's way, that is, to accept the laws that are good for the people, will, according to the 
Bible, be destroyed over a thousand-year period as part of the thousand-year resurrection of the righteous and the unrighteous...

Mrs. J. explained that over a thousand-year period the dead will rise and those who are unwilling to accept God's order will be destroyed forever. The majority of people will be returned to the earth, where, according to respondents, they will live forever under the rule of Jesus Christ and his 144000 anointed (the best of the Jehovah's Witnesses, and people with outstanding qualities, such as Moses). This limited number of faithful (144 000) will rule as immortal kings and priests with Christ in heaven and will have a non-material, spiritual form, while the rest will receive new bodies after the resurrection, material in form and essentially the same as the bodies they had in life. The main difference between the afterlife and current life lies in the non-existence of evil, suffering, pain, and death on the so-called New Earth (of the afterlife). Earth will then be an idyllic place that enjoys eternal peace, serenity, satisfaction, and prosperity. This Kingdom of God is seen as part of God's original plan, and Jehovah's Witnesses are convinced that the time of change is rapidly approaching and see the apparent increase in global disasters as a sign of this. Preaching about the imminence of God's Kingdom is one of the most essential elements of the missionary message of this international religious society.

The international society of Jehovah's Witnesses does not prescribe any specific funeral ceremony or method for disposal of the body, and in fact the funeral ceremonies of its members conform to the cultural background and traditions of the areas where the members live. Their doctrine merely requires that the body be treated with dignity and respect. But the funeral preferences of the Jehovah's Witnesses interviewed are significant in the context of contemporary Czech society. Preferences regarding how the body is handled after death strongly reflect the belief of Jehovah's Witnesses in the non-existence of a 'conventional' afterlife. Almost all the respondents ${ }^{11}$ expressed a preference for cremation without a ceremony, followed by the scattering of the ashes. Cremation is preferred by the majority of Czechs, but the scattering of the ashes is not a preferred practice. When respondents were asked why they preferred not to have a funeral ceremony, the majority stated that they wished to avoid the unnecessary emotional displays and scenes of mourning and sadness often witnessed during the funeral ceremony, despite the fact that Czech funerals, in general, are not considered to be overemotional. Although those Jehovah's Witnesses questioned overwhelmingly expressed a preference for cremation without a ceremony at the crematorium, they did not agree on the total absence of any kind of funeral ceremony. Three respondents described having a preference for a gathering of family and friends, separate from the disposal of the body, in a memorial ceremony at the Kingdom

11 The only exception was a female respondent who felt that what happens to her body after death was irrelevant. 
Hall. ${ }^{12}$ Perhaps one reason why other respondents did not mention this ceremony is that they do not consider it a funeral (which is what they were asked about), because the body of the deceased is not present, and traditional symbolic funeral decorations, such as wreaths and the wearing of black, are intentionally avoided. The form of this meeting differs in content from the traditional funeral in that it takes the form of a regular religious service. Mr. G. described the ceremony as follows:

On the one hand it [the memorial ceremony at the Kingdom Hall] is an opportunity to remember and say farewell to the deceased and on the other a reminder of the expectation of the resurrection. Thus, the purpose of such a ceremony differs from a conventional funeral, which, however, in some cases may follow. ${ }^{13}$

What Mr. G. meant by saying the ceremony differs from a conventional funeral is that the aim of the ceremony is not primarily the physical disposal of the body but rather a spiritual celebration to both remember the deceased and to reiterate the biblical hope of resurrection. This ceremony is in no way intended to influence the afterlife of the deceased, as no such concept exists.

Members of the congregation do not usually become involved in the matter of the disposal of the body, which is seen as the family's responsibility. The memorial ceremony is organised independently of disposal. Czech Jehovah's Witnesses do not have any special traditions with regard to dealing with the body, generally leaving such matters to specialists (pathologists, funeral directors, and crematorium staff). They believe that the body after death has no further meaning or function, and therefore, it must simply be disposed of in a culturally acceptable way. Cremation followed by the scattering of the ashes is very well suited to this purpose, since both can be performed quickly and moreover there is no remaining physical evidence of the person, for example, in the form of a grave that can later be visited.

\section{The form and meaning of funeral rites}

A mutual relationship exists not only between notions of the afterlife and corresponding funeral preferences, but also between the traditions and practices of a given society, which influences contemporary rituals. Secularised rituals borrow certain symbols and meanings from traditional religious sources [ $c f$. Hervieu-Léger 2004], just as religious rituals are affected by non-religious practice,

${ }^{12}$ The usual ceremony takes place either in a crematorium or other (secular) hall suitable to the purpose.

${ }_{13}$ The funeral generally corresponds to the wishes of the close relatives of the deceased, who need not necessarily be of the same religious faith and may therefore prefer to arrange a conventional funeral ceremony for the deceased. 
especially in a highly secularised society [cf. Vandendorpe 2000; Garces-Foley and Holcomb 2006]. Official funeral rite practices generally originate in specific religious organisations (e.g. The Roman Catholic Order of Christian Funerals), but official rites are also determined by popular religiosity and secular practices, both of which play a particularly important role in secular or multi-faith societies [Larson-Miller 2006].

For religious believers, the conventions of the religious group to which they belong tend to put a check on their individual funeral preferences; although respondents may not in every case necessarily be aware of this fact. Even though more than one-third of Czech funerals take place without any form of ceremony organised by a funeral director, the respondents from religious groups expressed their preference for some kind of funeral service. Although this was taken as a given by Catholics and Protestants, Jehovah's Witnesses took a negative view of such ceremonies and strongly opposed traditional (Christian) funerals, preferring that the body be treated with the maximum of simplicity and the minimum of ceremony (cremation without a ceremony followed by the scattering of the ashes). The customs of Jehovah's Witnesses contrast sharply with those of other Christians, the vast majority of whom, irrespective of preferences for burial or cremation, opt to deposit the bodily remains in a grave or cemetery columbarium. The scattering of the ashes, preferred by Jehovah's Witnesses, is unusual in Czech society, but there is growing trend towards this form of disposal.

Conceptions about the afterlife and the alleged relationship between the dead and the living play an influential role in funeral rituals. Apart from determining the method of body disposal (burial or cremation; scattering the ashes or not), such conceptions also affect the mourning process. Praying for the deceased is most common among Catholics, who believe they are thereby able to affect the fate of the deceased. This practice was found to be less common among the Protestants of the Church of the Czech Brethren, whose funeral rituals focus less on the deceased and more on support for the bereaved. Jehovah's Witnesses, convinced that after death the deceased is temporarily non-existent, try to avoid mourning rituals altogether. The secular majority in society exhibit a similar attitude towards funeral rituals, but their reasons for doing so differ from those of Jehovah's Witnesses.

Personalised funerals, which in the past few decades have become increasingly popular in Euro-American culture [Howarth 1996; Vandendorpe 2000; Schäfer 2007; Walter 1990], are not common in either secular or religious communities in the Czech Republic. This is not owing to a lack of demand for them, but is rather because the needs of the bereaved are often unspecified and very few funeral directors are able to provide such services. The funeral industry does not work with privatised spirituality; it can accommodate either a Christian (or other established religious) ceremony or a secular one. There is no other model between the two. Most Czech funeral directors have been working in the field since the communist period and continue to offer services that are similar to those pro- 
vided then. Moreover, the bereaved traditionally prefer to take a passive role in organising funeral rituals, leaving as many details as possible to specialists. Traditionally, however, the family does organise the funeral meal [Ludvíková 1971; Navrátilová 2004: 239-241], which is usually held after the funeral ceremony, for close relatives and friends, in the home of the closest relative of the deceased (or in a restaurant). This tradition is more common in smaller towns and villages than large cities. During the funeral meal, people often remember the deceased in informal talk and recall stories from their life. A personal aspect is thus introduced through this practice, which often serves to supplement the impersonal nature of the funeral ceremony. However, funeral meals usually take place after a funeral, so if there is no ceremony it often does not take place at all.

Religious rituals tend to limit the extent to which a funeral can be personalised, because priests generally follow prescribed practice, which stresses theological concepts rather than the personality of the deceased. Furthermore, as far as cremation is concerned, the priest may be able to influence only a small part of the ceremony (the speech), which is most often held, in accordance with secular practice, in a secular crematorium. Naturally, if the ceremony is held at a place of worship, complete with religious symbols and rituals, the priest is able to play a more influential role. In both cases the extent to which the funeral can be personalised is limited by religious considerations.

Drawing on Walter's [1996] scheme of ideal types (in Weber's sense), according to which there are three types of death - the religious traditional death, the medical modern death, and the personal post-modern death - I would argue that the most common in the Czech context appears to be the medical modern death. Even though elements of all three types can be observed, most Czech people die in a hospital [Kalvach et al. 2004: 20-22], the body is subsequently handled by specialists such as coroners and undertakers; the family and the clergy play a relatively minor role. As far as believers are concerned, faith may influence which method of disposal of the body and type of funeral ceremony are chosen, but even in such cases the undertaker tends to exert a strong influence on the funeral rites, just as they do in organising the way in which the body is disposed of. Reliance on specialists, whether it is a funeral director or a priest, tends to limit personal choice. Owing to the legacy of state involvement during the communist regime Czech funerals continue to be institutionally commercial and choice is severely restricted.

In relation to funerals it is possible to draw on another concept of Walter, which categorises the prevailing way in which funerals are organised and the process of their organisation in the context of society, its religion, and its institutions [Walter 2005]. In the Czech Republic, control of the funeral industry has been granted to private businesses in the form of funeral directors who pursue activities that were formerly (till 1990) regulated by the state. In comparison with the United States, which also follows the commercial model of funeral services, the situation in the Czech Republic is quite different owing to the short history of 
this commercial field and owing to cultural differences. The very different view of religion in the culturally religious United States and the culturally secular Czech Republic is also a source of differences in this business. With regard to religiousness, it would be interesting to compare Czech secular funeral rites with those in other highly secularised countries, such as the Netherlands, Sweden, or New Zealand; unfortunately it is beyond the scope of this paper to do so here. ${ }^{14}$ New rites are on the rise in multicultural Western societies, and this diversity is fuelled by immigrant populations, which bring with them different funeral customs and make the commercial model of funerals even more flexible [Howarth 2007: 247-249]. Again, however, this is not the case of the Czech Republic, which is still a very ethnically homogenous country with a very small proportion of immigrants.

\section{Conclusion}

The simplification of the funeral rite by the Czech secular majority is mirrored in the practices of religious believers, the majority of whom tend to choose funeral rituals primarily on the basis of the traditions of the group to which they belong. Personal preferences are most often adjusted to accommodate accepted religious customs. At the same time, religious funerals are to a certain degree influenced by the way in which funerals are conducted in the secular majority, especially when the funeral takes place in a crematorium.

During the course of the research, an important relationship was identified between membership of specific religious groups and preferences concerning funeral rites and, to a lesser extent, between denominations and the meaning assigned to funeral rites. The funeral was seen by most of the Catholics interviewed as a separation as it was by a number of Protestants and Jehovah's Witnesses. The funeral preferences of the Jehovah's Witnesses were most clear and group-uniform, i.e. cremation followed by the scattering of the ashes. Conversely, Catholics showed a clear preference for the traditional burial in a grave; Protestants were most ambiguous about the choice of funeral, showing a slight preference for cremation. None of the respondents felt that the form the funeral takes has any significant influence on the afterlife. The funeral was seen primarily as being more important for the bereaved than the deceased.

The majority of the Catholics interviewed saw the funeral as a dignified farewell with prayers being said to assist the deceased in the afterlife. Protestants, more than the other two groups, saw the funeral in terms of support for the bereaved and in terms of its role in the mourning process (singing and reminders of the afterlife were seen as important components of the ceremony). Jehovah's

${ }^{14}$ On the situation in the Netherlands, see http://www.ru.nl/rdr/; on New Zealand, see Schäfer [2007]; on Sweden, see Dahlgren and Hermanson [2005] and Reimers [1999]. 
Witnesses viewed the whole funeral concept in negative terms and were critical of the display of emotions during the ceremony, which, they felt, was harmful to the bereaved. In contrast to the other two Christian groups, they prefer a simple memorial service without the body, leaving no physical location (a grave or columbarium) for the bereaved to visit.

In Czech society, omitting the funeral altogether has been on the increase amongst unbelievers since the fall of the communist regime. Two main reasons are cited for this trend: first, that they wish to avoid the emotional stress brought on by the ceremony, and second, the cost of the funeral. The author argues that other reasons exist, namely, the low level of social cohesion (especially in larger towns), the anti-religious approach of the majority of the population for whom a religious ceremony is meaningless, and the lack of an emotionally fulfilling secular funeral ceremony. Even though the current trend is to minimise the funeral, keeping the remains together is still preferred (even if no funeral ceremony has been held) and despite the fact that the majority of the dead are cremated, the most common practice is to deposit the cremated remains in a grave or, less often, in a cemetery columbarium. The individualisation of the funeral, with fewer people taking part in the last rites (only the closest relatives and, possibly, friends of the deceased, as well as a number of specialists), is on the increase. It is expected that funeral practices will become increasingly personalised, catered for by a new generation of undertakers who will try harder to meet the needs of the bereaved than their communist era predecessors for simple commercial reasons. Consequently, funeral trends are probably set to change and the relatively high number of deceased or bereaved deciding to omit the funeral altogether might well decrease. As rituals are dynamically transforming according to the changes of society, last rites in the Czech Republic should become more diverse and complex and new forms should emerge in near future.

Olga NeŠPOROVÁ is a researcher at the Research Institute for Labour and Social Affairs and a PhD student in social anthropology at the Faculty of Humanities of Charles University in Prague. Her main research interests are changes in the family, attitudes towards death, last rites, values, and the religiosity of contemporary society.

\section{References}

Babička, V. 2005. 'Vývoj katolické religiozity v Českých zemích v letech 1949-1989.' (Shifts in Catholic Religiosity in the Czech Lands from 1949 to 1989) Sborník archioních prací 55 (2): 379-506.

Berger, P. L. and T. Luckmann. 1967. The Social Construction of Reality: A Treatise in the Sociology of Knowledge. London: Penguin.

Dahlgren, C. and J. Hermanson. 2005. 'Sweden.' Pp. 60-64 in Encyclopedia of Cremation, edited by D. J. Davies and L. H. Mates. Aldershot: Ashgate. 
Garces-Foley, K. and J. S. Holcomb. 2006. 'Contemporary American Funerals: Personalizing Tradition.' Pp. 207-227 in Death and Religion in a Changing World, edited by K. Garces-Foley. New York and London: M. E. Sharpe.

Gennep, A. van. 1960. The Rites of Passage. London: Routledge \& Paul.

Hamplová, D. 2000. Náboženství a nadpririrozeno ve společnosti. (Religion and the Supernatural in Society. An International Comparison Based on ISSP Empirical Research) Prague: Sociologický ústav AV ČR.

Haškovcová, H. 2000. Thanatologie. Nauka o umírání a smrti. (Thanatology: The Science of Dying and Death) Prague: Galén.

Hervieu-Léger, D. 2004. 'Un rituel funéraire de haute modernité. Étude de cas.' Pp. 1608-1624 in La Mort et l'immortalité. Encyclopédie des savoirs et des croyances, edited by F. Lennoir and J. P. de Tonnac. Paris: Bayard.

Howarth, G. 1996. Last Rites. The Work of the Modern Funeral Director. Amityville, New York: Baywood Publishing Company.

Howarth, G. 2007. Death and Dying. A Sociological Introduction. Cambridge: Polity.

Jupp, P. C. and T. Walter. 1999. 'The Healthy Society: 1918-98.' Pp. 256-282 in Death in England, edited by P. C. Jupp and C. Gittings. Manchester: Manchester University Press.

Kalvach, Z., J. Mareš, L. Prudký, O. Ptáček, O. Sláma, M. Špinková and Š. Špinka. 2004. Umírání a paliationí péče v ČR. (Dying and Palliative Care in the Czech Republic) Prague: Cesta domů.

Kandert, J. 2005. 'Pohřební čas ve středoslovenských vesnicích.' (The Mourning Period in Villages in Central Slovakia) Pp. 251-255 in Cesty na druhý svet, edited by M. Kováč, A. Kovács and T. Podolinská. Bratislava: CERES.

Kubíčková, N. 2001. Zármutek a pomoc pozůstalým. (Grief and Assistance to the Bereaved) Prague: ISV.

Larson-Miller, L. 2006. 'Roman Catholic, Anglican, and Eastern Orthodox Approaches to Death.' Pp. 93-121 in Death and Religion in a Changing World, edited by K. Garces-Foley. New York and London: M. E. Sharpe.

Ludvíková, M. 1971. 'Pohřební pohoštění a hostiny.' (Funeral Meals and Banquets) Národopisné aktuality 8 (3): 211-220.

Maiello, G. 2005. 'Současné pohřební rituály v českých zemích na př́kladu krematorií v Praze-Strašnicích, Zlíně a Plzni.' (Contemporary Funeral Rites in the Czech Lands Using the Examples of Crematoria in Prague-Strašnice, Zlín and Plzeň) Český lid 92: 35-47.

Malinowski, B. 1948. Magic, Science and Religion and Other Essays. Boston: Beacon Press.

Merridale, C. 2000. Night of Stone. Death and Memory in Russia. London: Granta Books.

Navrátilová, A. 1989. 'K analýze tendencí vývoje rodinných obřadů na současné vesnici. Obřady, spojené s úmrtím a pohřbem.' (Trends in Family Ceremonies in Contemporary Villages. Last Rites) Český lid 76 (3): 149-155.

Navrátilová, A. 2004. Narození a smrt v české lidové kultuře. (Birth and Death in Czech Folk Culture) Prague: Vyšehrad.

Nešpor, Z. R. (ed.) 2004. Jaká víra? Současná česká religiozita/spiritualita z pohledu kvalitativní sociologie náboženství. (What Faith? Contemporary Czech Religiosity/Spirituality from the Perspective of the Qualitative Sociology of Religion) Prague: Sociologický ústav AV ČR.

Nešporová, O. 2004. 'Existenciální dimenze současné církevní zbožnosti. Katolíci, protestanti, svědkové Jehovovi a oddaní Kršny ve vztahu ke smrti a posmrtné existenci.' (The Existential Dimension of Contemporary Church Religiosity. Catholics, Protestants, Jehovah's Witnesses and Hare Krishna Devotees in Relation to Death and Afterlife Existence) Pp. 38-55 in Jaká víra? Současná česká religiozita/spiritualita z pohledu 
kvalitativní sociologie náboženství, edited by Z. R. Nešpor. Prague: Sociologický ústav AV ČR.

Nešporová, O. 2007. Smrt, umírání a pohřební rituály v české společnosti 20. století. (Death, Dying and Funeral Rites in Czech Society in the 20th Century) Soudobé dějiny 14 (2-3): 352-376.

Reimers, E. 1999. 'Death and Identity: Graves and Funerals as Cultural Communication.' Mortality 4 (2): 147-167.

Schäfer, Cyril. 2007. ‘Post-Mortem Personalization: Pastoral Power and the New Zealand Funeral Director.' Mortality 12 (1): 4-21.

Steindl, R. 1987. Kontinuita života. Vztah života a smrti od starověku po současnost. (The Continuity of Life. The Relationship between Life and Death from Antiquity to Present Times) Prague: Mladá fronta.

Turner, V. W. 1974. The Ritual Process: Structure and Anti-structure. Harmondsworth: Penguin.

Vandendorpe, F. 2000. 'Funerals in Belgium: the Hidden Complexity of Contemporary Practices.' Mortality 5 (1): 18-33.

Walter, T. 1990. Funerals: and How to Improve Them. London: Hodder \& Stoughton.

Walter, T. 1994. The Revival of Death. London: Routledge.

Walter, T. 1996. 'Facing Death without Tradition.' Pp. 193-204 in Contemporary Issues in the Sociology of Death, Dying and Disposal, edited by G. Howarth and P. C. Jupp. London: Macmillan Press.

Walter, T. 1999. On Bereavement. The Culture of Grief. Buckingham: Open University Press.

Walter, T. 2005. 'Three Ways to Arrange a Funeral: Mortuary Variation in the Modern West.' Mortality 10 (3): 173-192. 